\title{
A better class of pauper? \\ From Kent to Port Nicholson
}

\section{FRANCIS KING}

It is perhaps a bit of a cheek for an Englishman, and a newly arrived one at that, to be writing about New Zealand history. However, I take heart that H.R.F. Keating, whose 'Inspector Ghote' novels brilliantly evoke both the squalor and the grandeur of Mother India, didn't actually set foot in the sub-continent until after his fifth best-seller.

While casting around in Britain for a subject for a short dissertation. ${ }^{1}$ I came across an interesting little notebook in the Kent Archives Office in Maidstone. ${ }^{2}$ This seemed to be the personal accounts book of the Reverend Hornbuckle, Vicar of Staplehurst in the Weald of Kent, for the years 1830 to 1843. Part of the book kept tally of the amount of work various labourers had done in the churchyard to repay loans. The main content, however, was a record of payments made against the Poor Rate to assist the emigration of six families from the Staplehurst Workhouse to New Zealand in 1839.

I decided to follow the fortunes of these six

A view of the sleepy village of Staplehurst, probably taken in the 1930s. It has changed little since then, nor much since 1839. The first house on the right is said to have been where the Averys lived.

[Photograph by R. Cole \& Son, by courtesy of Mrs. Phyllis Avery of Feildingl

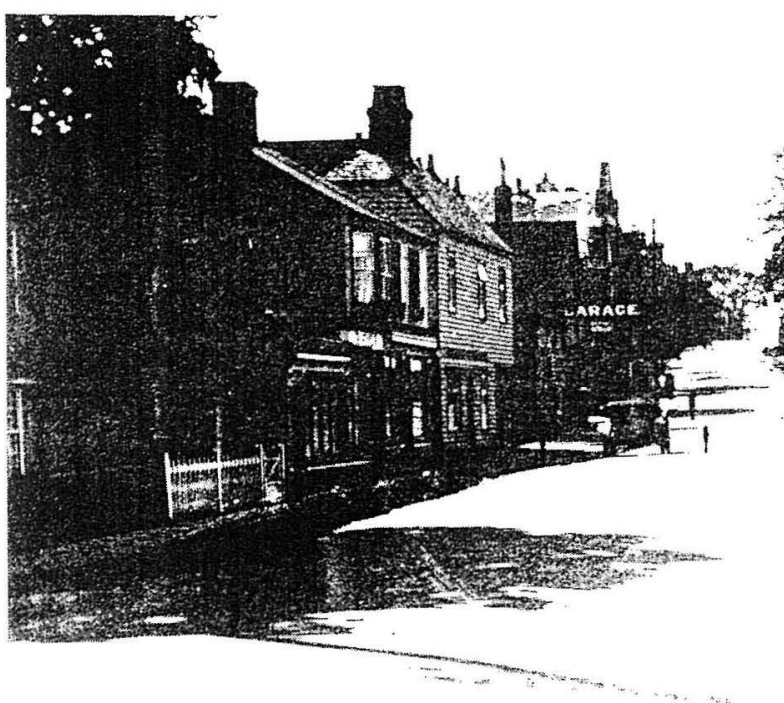

families, made up of forty-seven men, women and children, who sailed on The Bolton arriving in Port Nicholson in April, 1840. I was very fortunate that for three out of my six families there was good information available. The Avery and Nash families ${ }^{3}$ have very able genealogists as descendants, and the Peckham family was included in A.H. Carman's Tawa Flat and the Old Porirua Road. ${ }^{4}$ For the Farmer, Hunt and Relph families, however. I had to start from the basic clay of Births, Deaths \& Marriages Registers, Jurors Lists and Electoral Rolls. I will be describing the genealogical part of my study in more detail in an article for the Genealogical Research Institute of New Zealand Yearbook. What I wish to discuss here is why the New Zealand Company chose to grant free passage to these families consigned to the Staplehurst Workhouse. At the same time I wish to reassure the present day descendants of these families. who are sometimes taken aback to discover that their ancestors came from the Workhouse.

The Wakefield system of settlement had at its core two principles. The first was to obtain land cheaply, sell this to speculators and use the money so gained to subsidise the emigration of hand-picked, but landless, labourers. The second was to create in the new country a microcosm of all that was best in English society. As a minor aristocrat. Wakefield considered the 
English class system of landlord and tenant to be part of the natural order of things:

The rich man in his castle,

The poor man at his gate....

However, it was one thing to theorise from inside the walls of Newgate prison, ${ }^{5}$ it was another to put it into practice. The Whig government of Lord Melbourne, urged on by the Church Missionary Society, had finally but reluctantly, decided that the Maori of New Zealand ought to be protected from the depredations of traders and settlers through the proclamation of British sovereignty. They had begun to make plans to send out Captain Hobson to draw up a treaty with the Maori. The New Zealand Company knew that the Government monopoly on land purchases, which would inevitably follow, would effectively scupper their Wakefieldian schemes. So haste was of the essence. An indication of this, is that the first land purchases from the Maori, in Port Nicholson, took place on 27 September 1839, twelve days after The Oriental, full of emigrants left London for New Zealand.

In the few weeks available to them, for this first phase of settlement, it was very difficult for the Company agents to secure the right kind of emigrant. The country was literally at the other end of the world, the Maori were reputed to be warlike and unfriendly, it was much cheaper, quicker and simpler to emigrate to North America, where so many others had gone before. The Company made it no easier for the hard-pressed recruiting agent by being extremely selective. The Company embarkation order records ${ }^{6}$ show just how few emigrants were actually chosen from the huge numbers proposed by agents.

Emigration was not entirely free either, even for those adults granted free passage. Children, other than infants in arms and teenagers old enough to work, had to be paid for. The Company insisted that all emigrants must be properly clothed for the future climatic rigours and that artisans should bear with them their tools. Then there was the fare from home to the point of embarkation. Thus the New Zealand Company enmeshed itself in a fine dilemma, Labourers rich enough to afford emigration to New Zealand were either sufficiently well off not to wish to change their status quo, or would rather emigrate to North America or Australia, which was not entirely terra incognita.

In desperation, the agents looked towards the Workhouses to fill the emigrant ships which had been so expensively hired. So high a proportion of early emigrants on the first ships into Port
TO SOBER AND INDUSTRIOUS Igricultural Laborers. HE NEW ZEALAVD LAND COMPAN Governor, The Earl of Durham, Depexty=Governor, Toseph Somes, Ese:DIRECTORS,

Lord Petre
Huil Francis Baring, M.P.
J. Ellerker Boulcolt, Esq.
Juhn William Buckle, Esq.
Gussell Ellice. Esq.
J. Brodie'Gurdon, Esq. T. Alers Hankey, Esq.
Willinm Hutt, Esq. H.P.
Siewart Nirjoribanka. Es Sir G. Sioclair, Bt. M.P.
J. Abel Smith, Esq. M.P.

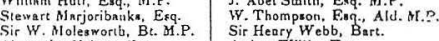
Alexander Nairne, Hisq. Sir Heary Webb, Bart. Arthur Willis, Esq.
George Frederick Young. Es?.

HEREBY GIVE NOTICE, That a Gentleman from their Office in London will attend, to receive applications for a

:REE PASSAGE TO NEW ZEALANI

(to Sail on or about the Ist of November, by the Ship Bollon), from Country Laborers only, at the follorving times and places:-

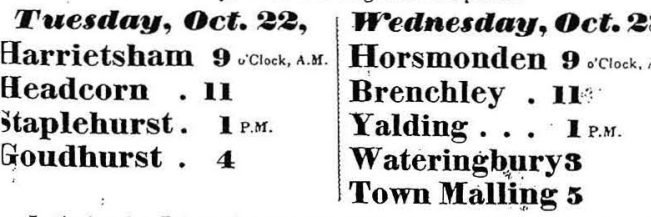

I In the interim, Printed Forms of Application may be abtained, together wit information respecting New Zealand, at the Company's Office, No. 1, A dor Street, Adelpbi; or from Mr. G. WHITING, Agent to the New Zealand, Cor: pany, No. 3, Marsham Pláce, Maidstone.

October 12,1839 JOHN WARD, Secretary.

PRITTRD DY I. A. CUTDUSII AND SON, WEEK STREET, MAIDSTONE.

Poster advertising the visit of an agent of the New Zealand Company, probably George Whiting himself, to the depressed villages of the Weald. Without doubt, it was a copy of this poster which was seen by the six families. Original in CO 208 291-295. New Zealand Company Scrapbook, 1839 onwards. held in the Public Records Office, Kew, London.

(Due to the manner of storage of the original, it is only possible to reproduce this poster slightly cropped - ed.)

Nicholson were paupers, that Colonel William Wakefield, the New Zealand Company's agent in Wellington, complained that they were the scourings of Gravesend and neighbouring Workhouses, recruited less through a desire for quality than a need to fill up ship's berths. ${ }^{7}$

Since 1834 and the introduction of the 'New' Poor Law, parishes had been legally entitled to charge the emigration of paupers' expenses against the Poor Rate. It made good economic sense to spend extra one year to despatch the parish paupers, to lessen expenditure subsequently. The problem was that, whereas the Poor Law Commissioners accepted this charge for emigration to Canada and Australia, New Zealand was a new proposition.

There is an interesting exchange of correspondence between the Poor Law Commissioners in Somerset House and the Colonial Office, on 30 October $1839 .^{8}$ in which the Commissioners seek the advice of the Colonial Secretary as to the propriety of subsidising emigration to New Zea- 
land for a group of paupers from Staplehurst. The reply came by return:

There is no British Colony at New Zealand nor is it yet clear that such a Colony will ever be established. The Government has repeatedly and distinctly refused to recognise any of the Companies and Associations which have been formed for sending Settlers to these islands. Capt. Hobson has been accredited to the native Chiefs as H.M's Consul and has been authorised to negotiate for the surrender to H.M. of the Sovereignty of such parts of New Zealand as he may think best adapted as a British Colony. Until the rest of his negotiations are known, the Government must consider New Zealand as a foreign country of which Great Britain has acknowledged the independence and National flag.

In the face of such a definite negative, the Poor Law Commissioners had no option but to forbid the subsidy of the six families. But we know that, in fact, they were helped by the Parish and out of Poor Law taxation.

Two years after the Staplehurst emigration. on 22 September 1841, George Whiting wrote to Mr. Alston, Secretary to the New Zealand Company, asking permission for discretion to waive the payment for children which he had heard was happening elsewhere. He went on to say:

This information has reached Parochial Officers who have at all times shown great repugnance to pay this money in defiance of the Poor Law Commissioners, but who would nevertheless manage to smuggle [Whiting's emphasis] the expenses of outfit and conveyance of many highly desirable persons. ${ }^{9}$
This brings us back to our six pauper families from Staplehurst. It seems probable to me that as it was George Whiting, emigration enthusiast, editor of the Maidstone Journal and agent for the New Zealand Company who presented them, that it was to the endeavours of himself and the Reverend T.W. Hornbuckle that this letter refers. This also explains why Hornbuckle's accounts had to be kept in a private notebook and not in the main ledger.

What this does not explain, however, is why Whiting and Hornbuckle should go to such lengths in flouting the law to give these six families a chance of a new life in New Zealand. Perhaps the answer is that they were not dross, after all and that Whiting saw them as most desirable emigrants.

It was certainly true that the workhouses of Kent were unusually full at that time. The agricultural boom in the south of England, caused by the need to victual an expeditionary army on the Continent, was ended by the Battle of Waterloo. Newly-invented threshing machines threatened the agricultural labourer's livelihood. Hops were no longer a paying proposition.

An impression by Alfred Memelink of the Bolton on its first voyage to New Zealand, entering Port Nicholson by the Heads with its cargo of immigrants, including the six families from Staplehurst. Reproduced by kind permission of the artist. Numbered prints of this picture and three other scenes of early immigrant ships may be purchased at the Maritime Museum, Wellington, and at the Early Settlers Museum. Petone.

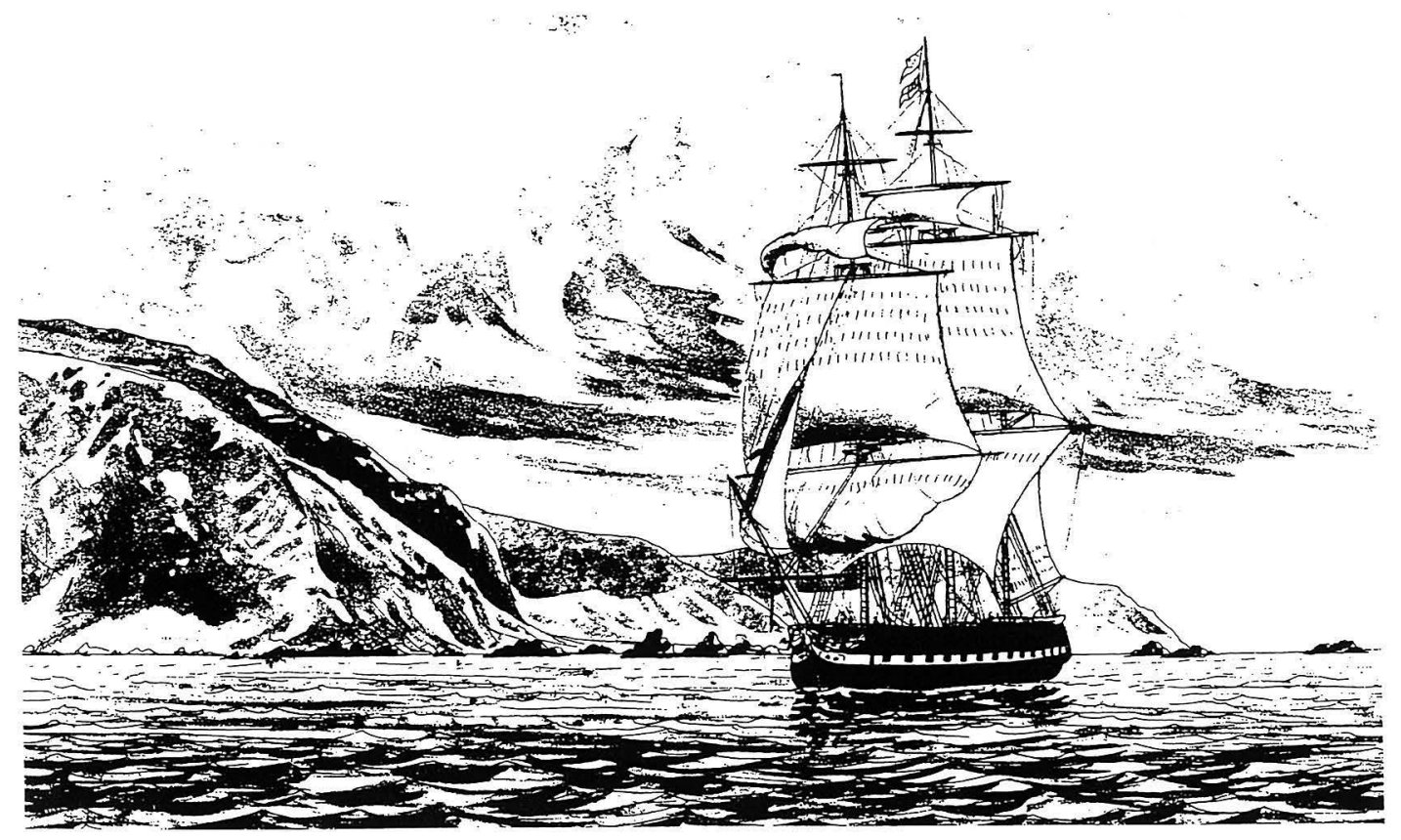


Whiggish free-marketeers then, as now, lifted taxes on foreign imports, to the detriment of home produce, in this case fruit. This had also made smuggling uneconomic, which must have had some impact on the Weald, a well used conduit for contraband. Agriculture in the Weald was always a struggle, its cold, grey clays were notoriously hostile to human effort. A letter from Robert Woodman, to his brother, Thomas, who had emigrated from nearby East Farleigh on the same ship as the six families, sums it up:

I am sorry that Mary wants to come back so well, as she knows what this country is. The truth is that every day gets worse and is likely to continue. So Ned Bishop and his young brother Bill and young George Turner are gone to America. John Stacey is gone to Australia and thousands more are every day leaving this country for different parts of the world. They say that anywhere is better than starving at home. ${ }^{10}$

The six families had not been in the Workhouse during the summer. They were happy to take work when it was available and make do without parochial care. But with the onset of autumn, the advertisement for New Zealand emigration especially for labourers, must have seemed like the answer to a prayer. Perhaps, while on this subject, it is worth noting that of the six heads of family, William Peckham was a keen member of the Primitive Methodist persuasion, James Henry Nash became a Methodist Lay Preacher and Thomas Avery's pious Anglicanism remains a family tradition. These were not down and outs but people for whom the economics of maintaining a large family in hard times periodically became too much. Hobsbawm and Rudé have calculated that in sixteen Kent parishes in 1824, more than one third of the inhabitants were paupers. ${ }^{11}$ It is probable that in Wealden parishes, the number was higher still.

'By their fruits ye shall know them' is perhaps the acid test. Were the expectations of Whiting and Hornbuckle realised by the families when they got to Wellington? The following contemporary description of a labourer in Wellington, is almost certainly of Thomas Avery:

There is a poor man close to me that came out with us; I am very partial to him; he comes out of Kent: has a wife and eight children; and told me when he landed he had only $6 \mathrm{~d}$. in the world; he has now got $£ 60$ in gold, and bought a piece of land to put a house on, which cost £90; he is a labourer. and his lads the same; his wife washes for hire. ${ }^{12}$

Of the three families for whom I have good records, William Peckham, a sawyer, owned forty-one acres on the Old Porirua Road by 1875 . James Henry Nash, a ropemaker, came to own his own ropewalk, was a founder of the Manawatu flax trade and was the local preacher in the chapel he had set up. A descendant became Mayor and MP. for Palmerston North. By 1882 the value of the property owned by the Avery family was nearly two thousand pounds. Present day descendants include farmers, Sir Frank Renouf and the last Prime Minister, Mike Moore.

George Whiting and the Reverend T.W. Hornbuckle were right to recognise emigration to New Zealand as an opportunity for these families to realise their true potential.

1. I was two years into a three-year part-time Diploma of Local History at the University of Kent at Canterbury. when I was posted as British Council Director and Cultural Attaché to Wellington. Such a Kentish topic in New Zealand for the dissertation seemed the best way of making a virtue out of a necessity. It is a pleasant irony that the University in Canterbury. England, built in the 1960 s, was not able to call itself such, as the title was pre-empted by the far older University of Canterbury. New Zealand.

2. P347 12/27, Accounts Book, Rev. T.W. Hombuckle, 1830 1843. Kent Archives office, Maidstone, Kent.

3. These are Cecil \& Phyllis Avery, and their daughter Diane Young of Fielding, Bernie Black of Auckland and Jean McDonald of N.S.W. Australia, for the Avery Family; Susan Webb of Wadestown and Moss and Shirley Collins of Matamata for the Nash family. All these genealogists have been enormously generous with their time and research. I owe them a great deal.

4. Arthur C. Carman, Tawa Flat and the Old Porina Road, 1840-1955, Wright \& Carman, Wellington. 1955.

5. To induce a wealthy Macclesfield mill-owner to return him to Parliament as an MP. Wakefield abducted the millowner's teenage daughter from her school and went through a form of marriage with her in Paris. He was lucky to escape with a mere three-year term in Newgate prison for this escapade. He made good use of his time in gaol by formulating his theory of emigration. Unable to follow a Parliamentary career, he expended his considerable energy and proseletysing skills on propagating his ideas on his release from prison.

6. CO 208 272/273, Register of Applications for Free Passage to New Zealand, 1839-1845. Public Records Office, Kew, London. A good set of photocopies sits on the open shelves of the Alexander Turnbull Library in Wellington.

7. CO 208 127, Letter from Col. Wm Wakefield to Mr. Alston, Secretary of the N.Z. Co.. 25 February. 1841. Public Records Office, Kew, London.

8. MH 12 5196, Maidstone Union, Poor Law Records, 18381840, Public Records Office, Kew, London.

9. CO 208 8, Bundle of Letters, (misc.) N.Z. Co., 1839 onwards. Public Records Office, Kew, London.

10. Robert Woodman, Letter to Mr. Thomas Woodman of Bolton Row, Wellington Town, I January 1842. Origi$\mathrm{nal}$ in the possession of Thomas' great, great grandchild, Barry Jones of Hastings, N.Z.

11. Hobsbawm and Rudé. Captain Swing, Penguin. Harmondsworth, 1973.

12. William Bannister, Letter. 14 April 1841, quoted in The New Zealand Journal, 1841, p. 298.

Francis King was educated at Oxford University. He is Director of the British Council in New Zealand. This article is adapted from a Stout Centre Seminar held on 24 April, 1991. 